\title{
Archipel
}

ARCHIPEL Études interdisciplinaires sur le monde insulindien

$99 \mid 2020$

Varia

\section{Filmed Memories of 1965}

Filmed Memories of 1965

\section{Elsa Clavé}

\section{(2) OpenEdition \\ Journals}

\section{Electronic version}

URL: http://journals.openedition.org/archipel/1639

DOI: 10.4000/archipel.1639

ISSN: 2104-3655

\section{Publisher}

Association Archipel

\section{Printed version}

Date of publication: 15 July 2020

Number of pages: 19-21

ISBN: 978-2-910513-83-2

ISSN: 0044-8613

\section{Electronic reference}

Elsa Clavé, "Filmed Memories of 1965", Archipel [Online], 99 | 2020, Online since 02 June 2020, connection on 15 March 2021. URL: http://journals.openedition.org/archipel/1639; DOI: https:// doi.org/10.4000/archipel.1639 


\title{
DOSSIER 1965 AND CINEMA, II Coordinated by Elsa Clavé
}

\author{
ELSA CLAVÉ'
}

\section{Filmed Memories of 1965}

The fall of Suharto on May 21, 1998 ended the regime he had established 32 years earlier when an attempted putsch by a faction of the army turned in his favour. The abduction of six generals and one lieutenant initially intended to protect president Sukarno, finally triggered his political end when the officers were killed and the Indonesian Communist Party accused of having masterminded the event. During the three decades of the New Order's regime, the legitimacy of Suharto and the evil character of the communists he defeated - allowing the killing of half a million people and the imprisonment of many others - have been at the centre of the politics of memory. ${ }^{2}$ Many believed that the collapse of the New Order and the advent of the Reformasi would put an end to it. But collective memory, to use the term famously coined by Halbwachs, works in a complex way. It is institutionalized through museums, monuments, and if the commemoration is not as important as it used to be, the collective memory formed during the New Order has not changed much. The attack in 2017 by a mob on the Legal Aid Foundation's office suspected to host a meeting of communists in Jakarta, ${ }^{3}$ or the statements by officials against a latent danger (bahaya laten), remind us that the stigma attached to communism remains present and easy to manipulate. Ironically, the defiance

1. Asien-Afrika-Institut, Universität Hamburg.

2. Katharine McGregor. History in Uniform: Military Ideology and the Construction of Indonesia's Past. Singapore: NUS Press, 2007.

3. On this question, see the analysis of S. Wieringa, Archipel, 95, 195-210. 
toward communists even appears in works which claim to rehabilitate the victims ${ }^{4}$ and which are also sometimes part of the numerous initiatives for truth and reconciliation started mostly after the Reformasi.

Among those initiatives, the publications strike by the unbalance between the wealth of information they offer and the echo they find in the general audience. Over the past ten years, dozens of books have been published in Indonesia unraveling the obvious lies of the previous regime. These academic studies, memoirs, and collections of testimonies presenting different voices have only reached a fringe of the population. The reasons are to be searched in the number of copies, too low, and the restricted distribution, but also in the format of the media which is directly related to the socio-cultural processes involved in collective memory-making. ${ }^{5}$

This is the reason why the films presenting alternative versions of the 1965-1966 events form an interesting addition to the growing body of sources. They remediate narrative elements which have often been published in other media, adding to it a powerful visual dimension. But they do not just present historical events, they also form an archive of the cultural memory. The films are examples of the way Indonesians relate to this painful past in their present. The four films presented in this issue of Archipel continue the panorama started in the previous issue with reviews of The Act of Killing by Joshua Oppenheimer, the Soliloque des Muets by Stephane Roland, and Surat dari Praha by Angga Dwimas Sasongko.

The Women and the Generals (2013), reviewed by Saskia Wieringa below, deconstructs one of the major lies of the campaign against the Communist Party: the sexual dance and the mutilation of the generals by women. It presents a careful investigation of the evidence, most of it available through academic publications, proving that the women organization affiliated to the communist party in 1965, Gerwani, had nothing to do with the murders but were targeted and annihilated because of their successful mobilization for social progress in the $1960 \mathrm{~s}$.

The second movie, Pulau Buru Tanah Air Beta (2016), reviewed by Vannessa Hearman, presents a well-known place related to the events: the island of Buru. This island has been turned into a concentration camp for long-time prisoners and is mostly known because the writer Pramoedya Ananta Toer has been imprisoned there. Interestingly, the film does not focus on the very hard condition of detention and the forced-labour but turns to the present and to the meaning of what remains. It follows the former detainee

\footnotetext{
4. The idea that numerous victims were not communists is very often put to the front. See as example the analysis of the movie "Surat dari Praha" by H. Chambert-Loir, Archipel 98: 2019, 69-70.

5. Astrid Erll and Ann Rigney (eds.). Mediation, Remediation, and the Dynamics of Cultural Memory, Berlin: De Gruyter, 2009.
} 
Hersri Setiawan, his wife, and daughter on the island while he and another ex-prisoner, Tedjabayu Soedjojono, ${ }^{6}$ recall the past while visiting places loaded with memories.

This attention to the second generation and the legacy which is passed on is at the centre of Forty Years of Silence: An Indonesian Tragedy (2009), reviewed by Soe Tjen Marching. The documentary presents the story of four families whose members had their mental health affected by the 1965-66 events. The director, who is a psychological anthropologist, wanted to bring to light the consequence of the violence on the health of victims' children. By showing the lasting impact of events which happened 55 years ago, Robert Lemelson also shows that silence does not erase the past and, on the opposite, makes it even more present.

On a very different way, the short animated-film A Daughter's Memory (2019), reviewed by Grace Leksana, gives also the voice to the child of a victim. The name of the victim is known by almost all Indonesians: it is Njoto, a major figure in the central committee of the Communist Party in 1965. Svetlana, one of his daughters, recalls her personal journey from the moment when her father was hunted by the army, to the present, through her period in prison and, later, hiding her identity.

As mentioned, these films are a sample of what is being produced, they are only the tip of the iceberg and about thirty film dealing with $1965-$ documentary or fiction - have been referenced so far. The list is not exhaustive and does not reference, for example, the films presented in the previous issue.

"Treachery on YouTube: Counter Narrative and Dynamics of Remembering and Forgetting the 1965/66 Tragedy", by Gilang Desti Parahita and Vissia Ita Yulianto, presents an acute analysis of the viewing and reception of such films on Youtube. The study shows that despite the multiplication of alternative narratives, their impact remains small compared to the State-sponsored version vehiculated by the movie Penumpasan Pengkhianatan G30S/PKI (The Eradication of the Treachery of the 30 September Movement/Indonesian Communist Party). If this movie has the advantage of time, because it is the oldest and the most known, it is also available in several formats on the platform and benefits of many supporters. It is hoped that the relatively new films presented here will be distributed more widely and will, in the future, enjoy the same privilege of having supporters to advertise it online.

6. Tedjabayu's story has been published in Archipel based on his unpublished memoirs. See Tedjabayu, "C'est la vie! Quatorze années de détention politique », Archipel, 97, 2019, 269-294. 
